\title{
Effect of magnesium addition on the structural homogeneity of NiTi alloy produced by self-propagating high-temperature synthesis
}

\author{
P. Salvetr*, A. Školáková, P. Novák \\ University of Chemistry and Technology, Prague, Department of Metals and Corrosion Engineering, \\ Technická 5, 16628 Prague 6, Czech Republic
}

Received 11 October 2016, received in revised form 26 May 2017, accepted 1 June 2017

\begin{abstract}
This paper shows that the addition of magnesium can improve the structural homogeneity of NiTi shape memory alloy produced by Self-propagating High-temperature Synthesis (SHS) by lowering the amount of undesirable brittle $\mathrm{Ti}_{2} \mathrm{Ni}$ phase. The formation of intermetallic compounds in the $\mathrm{Ni}-\mathrm{Ti}-\mathrm{Mg}$ ternary system was described on $\mathrm{Ni}-\mathrm{Ti}-\mathrm{Mg}$ compressed powder mixture using the differential thermal analysis. Magnesium was added to the NiTi46 wt.\% mixture in an amount of $5 \mathrm{wt} . \%$. The first intermetallic phases were formed at temperatures of $505^{\circ} \mathrm{C}$, and the SHS reaction started at $981^{\circ} \mathrm{C}$.
\end{abstract}

K e y w o r d s: nickel-titanium alloys, intermetallics, Self-propagating High-temperature Synthesis (SHS), shape memory, X-ray diffraction

\section{Introduction}

Intermetallic compounds in some alloy systems excel by unique properties. The system of aluminium and transition metals can have good mechanical properties at high temperatures and concurrently low density. Intermetallics based on nickel exhibit interesting properties such as hydrogen storage ability $[1,2]$ or shape memory effects $[3,4]$. Ni-Ti shape memory alloys are usually produced by melting metallurgy, which has a problem with high reactivity of Ni-Ti melt. Therefore it is necessary to use inert atmosphere (e.g., vacuum or argon atmosphere) and to choose a crucible material which cannot contaminate the Ni-Ti melt during Vacuum Induction Melting (VIM) [5-7]. Vacuum Arc Re-melting produces a melt with high purity, but melting must be repeated to get a homogeneous chemical composition of the product [8]. An alternative way of production of Ni-Ti alloys, being extensively studied, is Self-propagating High-temperature Synthesis (SHS). This method belongs to the group of Powder Metallurgy (PM) methods, and consists of heating of the compressed elemental powder mixture to a temperature at which exother- mic reaction between nickel, titanium or ternary alloying element is initiated. The initiation temperature of nickel-titanium mixture is variable depending on the used particle sizes of titanium and nickel powders [9]. This temperature decreases with increasing the heating rate to a temperature of $890^{\circ} \mathrm{C}$. The combustion reaction below $890^{\circ} \mathrm{C}$ was not observed by using high heating rate of $300^{\circ} \mathrm{C} \mathrm{min}^{-1}[10]$. The common problem of the Ni-Ti alloys production by methods of powder and melting metallurgy is the formation of the undesirable brittle $\mathrm{Ti}_{2} \mathrm{Ni}$ phase. The influence of powder sizes on combustion reaction and phase composition of the product was studied. It was found out that the amount of the $\mathrm{Ti}_{2} \mathrm{Ni}$ phase in the structure decreases with the use of middle particles sizes (25$45 \mu \mathrm{m}$ ) of nickel and titanium powders, higher sintering temperature and higher heating rate $[9,11-$ 13]. The influence of the ternary alloying element in Ni-Ti- $X$ system was studied and any of the alloying elements tested up to present time do not eliminate the formation of the $\mathrm{Ti}_{2} \mathrm{Ni}$ phase in the structure. Ternary alloying elements influence microstructure, phase composition, mechanical properties and modify the temperature of the NiTi phase formation

*Corresponding author: e-mail address: salvetrp@vscht.cz 
and transformation temperatures $[14,15]$. The values of transformation temperatures are very important properties for practical use of shape memory effects. Transformation temperatures are influenced by nickel-titanium ratio, a change in the content of nickel by 0.1 at.\% may change the transformation temperature by about $10^{\circ} \mathrm{C}$. It is known that selected alloying elements (iron, cobalt, vanadium, chromium, manganese, aluminium, and tantalum) decrease transformation temperatures. On the contrary, other alloying elements - hafnium, zirconium, palladium, platinum - are martensitic phase stabilisers $[16,17]$. Titanium has very high affinity for oxygen. In the Ni-Ti alloy, oxygen leads to the formation of oxidic compounds $\mathrm{Ti}_{4} \mathrm{Ni}_{2} \mathrm{O}_{x}$. The $\mathrm{Ti}_{2} \mathrm{Ni}$ phase can absorb oxygen until the formation of $\mathrm{Ti}_{4} \mathrm{Ni}_{2} \mathrm{O}$ (the calculated solubility of oxygen in $\mathrm{Ti}_{2} \mathrm{Ni}$ phase is lower than it measured [18]). On the other hand, NiTi phase absorbs a limited amount of oxygen only, see in the isothermal section of the ternary phase diagram for Ni-Ti-O at $925^{\circ} \mathrm{C}$ [19]. Therefore, the formation of the $\mathrm{Ti}_{2} \mathrm{Ni}$ phase is connected with the presence of oxygen in reaction atmosphere [16].

In this paper, we tried to eliminate the influence of oxygen on the reaction between nickel and titanium particles and decrease the amount of the formed $\mathrm{Ti}_{2} \mathrm{Ni}$ phase in the sintered product. It is to be carried by addition of magnesium as an alloying element because magnesium has higher affinity to oxygen than $\mathrm{Ni}-\mathrm{Ti}$.

\section{Experimental procedure}

Tested samples were prepared by blending from powders of the following purity and particles sizes - nickel powder (99.99 wt.\%, <150 $\mu \mathrm{m})$, titanium powder $(99.5$ wt. $\%,<44 \mu \mathrm{m})$ and magnesium powder (99.8 wt. $\%,<44 \mu \mathrm{m})$. Magnesium in the amount of 5 wt. $\%$ was added to NiTi46 wt.\% mixture (resulting chemical composition of the prepared powder mixture in wt.\% is Ni51.3Ti43.7Mg5). The mixture was uniaxially cold pressed at a pressure of $450 \mathrm{MPa}$ for $5 \mathrm{~min}$ to cylindrical green compacts $(12 \mathrm{~mm}$ in diameter and $5 \mathrm{~mm}$ in height) using LabTest 5.250SP1-VM universal loading machine. The SHS reaction was carried out at a temperature of $1100^{\circ} \mathrm{C}$ with a heating rate of $300^{\circ} \mathrm{C} \mathrm{min} \mathrm{m}^{-1}$ and process duration $20 \mathrm{~min}$ followed by cooling in air. The high heating rate was provided by insertion of the sample in preheated electric resistance furnace. The resulting chemical composition of the NiTiMg5 alloy was determined by X-ray fluorescence analysis (XRF). The metallographic samples were prepared from sintered products, the microstructure of the samples was revealed by etching in Kroll's reagent $\left(10 \mathrm{ml} \mathrm{HF}, 5 \mathrm{ml} \mathrm{HNO}_{3}\right.$ and $\left.85 \mathrm{ml} \mathrm{H} \mathrm{H}_{2} \mathrm{O}\right)$. The microstructure was observed by scanning electron microscope TESCAN VEGA 3 LMU equipped with

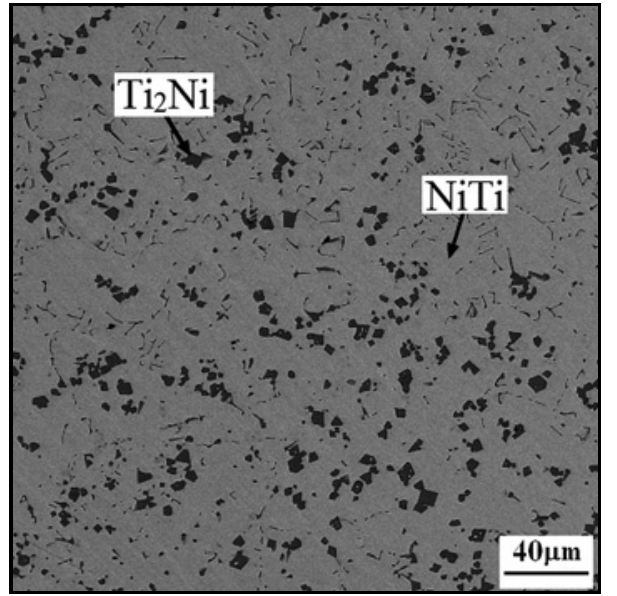

Fig. 1. The microstructure of Ni-Ti alloy produced by SHS at $1100^{\circ} \mathrm{C}$.

the OXFORD Instruments X-max $20 \mathrm{~mm}^{2}$ SDD EDS analyser for identification of chemical composition of individual phases. The phase compositions of the alloys were identified on ground surfaces of samples using X-ray diffraction (XRD) PANalytical X'Pert Pro diffractometer with a copper anode. The area fraction of the $\mathrm{Ti}_{2} \mathrm{Ni}$ phase was evaluated by Image J image analysis software. The Archimedes method was used for measuring of porosity. Mechanical properties were provided by micro hardness measurement of the $\mathrm{NiTi}$ phase (HV 0.01).

For an explanation of the reaction mechanism, the differential thermal analysis (DTA) of the Ni-Ti-Mg5 wt.\% compressed powder mixtures was performed using the Setaram Setsys Evolution device by heating from the laboratory temperature to $1200{ }^{\circ} \mathrm{C}$ with a heating rate of $30^{\circ} \mathrm{C} \mathrm{min}{ }^{-1}$ in the argon atmosphere and alumina crucible. The compressed samples in evacuated silica ampoules were sintered at temperatures of $510,600,800,900$, and $1000{ }^{\circ} \mathrm{C}$ with a heating rate $20^{\circ} \mathrm{C} \mathrm{min}-1$. These sintering temperatures were chosen according to the result of the differential thermal analysis to determine the phases' formation sequence. The process duration at the temperature was one minute with following quick cooling in water.

\section{Results and discussion}

If we compare the microstructure and mainly the amount of the $\mathrm{Ti}_{2} \mathrm{Ni}$ phase of $\mathrm{Ni}-\mathrm{Ti}$ alloy in Fig. 1 and NiTiMg5 alloy (both alloys prepared by SHS at a temperature of $1100^{\circ} \mathrm{C}$ ) in Fig. 2, we can observe quite different microstructures of both alloys. The structure of NiTiMg 5 alloy is more porous, and the $\mathrm{Ti}_{2} \mathrm{Ni}$ phase occupies $3 \%$ of the area fraction, whereas Ni-Ti alloy contains $13 \%$ of the $\mathrm{Ti}_{2} \mathrm{Ni}$ phase. The magnesium is the first alloying element which decreases the 




Fig. 2. The microstructure of NiTiMg5 alloy produced by SHS at $1100^{\circ} \mathrm{C}$.

Table 1. Chemical compositions of NiTi and $\mathrm{Ti}_{2} \mathrm{Ni}$ phases in Ni-Ti46 and NiTiMg5 alloys sintered at $1100^{\circ} \mathrm{C}$

\begin{tabular}{lcccccc}
\hline \multirow{2}{*}{ Phase (wt.\%) } & \multicolumn{2}{c}{$\mathrm{Ni}-\mathrm{Ti} 46$} & & \multicolumn{3}{c}{ NiTiMg5 } \\
\cline { 2 - 3 } \cline { 6 - 7 } \cline { 5 - 7 } & $\mathrm{Ni}$ & $\mathrm{Ti}$ & & $\mathrm{Ni}$ & $\mathrm{Ti}$ & $\mathrm{Mg}$ \\
\hline $\mathrm{NiTi}$ & 54.6 & 45.4 & & 53.9 & 45.7 & 0.4 \\
$\mathrm{Ti}_{2} \mathrm{Ni}$ & 37.5 & 62.5 & 32.2 & 67.8 & - \\
\hline
\end{tabular}

amount of the $\mathrm{Ti}_{2} \mathrm{Ni}$ phase in structure. The chemical compositions of individual phases are placed in Table 1 . The previous alloying elements (e.g. aluminium, chromium, iron, and vanadium) added to $\mathrm{Ni}-\mathrm{Ti}-X$ mixture mostly increased or retained approximately the same amount of the $\mathrm{Ti}_{2} \mathrm{Ni}$ phase [20]. The addition of magnesium decreases hardness of NiTi phase ( Ni-Ti46 = 383 HV 0.01 and NiTiMg5 = 329 HV 0.01).

On the DTA curve of Ni-Ti-Mg5 mixture (Fig. 3), there are three exothermic peaks. The first peak has its maximum at approx. $505^{\circ} \mathrm{C}$ (labelled 1). According to the XRD analysis of the sample annealed at $600{ }^{\circ} \mathrm{C}$ this thermal effect is associated with the formation of $\mathrm{MgNi}_{2}$ and $\mathrm{Ti}_{2} \mathrm{Ni}$ phases, see Fig. 4. In the microstructure of the sample heated to $600{ }^{\circ} \mathrm{C}$, there are nickel particles with a layer of the $\mathrm{MgNi}_{2}$ phase and titanium powder particles surrounded by thin layer of the $\mathrm{Ti}_{2} \mathrm{Ni}$ phase (Fig. 5a). It indicates that the first peak on the DTA curve is caused by the concurrent formation of $\mathrm{Ti}_{2} \mathrm{Ni}$ and $\mathrm{MgNi}_{2}$ phases similar to the formation of $\mathrm{Ti}_{2} \mathrm{Ni}$ phase at $504^{\circ} \mathrm{C}$ in $\mathrm{Ni}$ - Ti powder mixture in our previous work [21]. The maximum of the second exothermic effect was found at $720^{\circ} \mathrm{C}$ (labelled 2 in Fig. 3). This effect is relatively weak and long, which indicates a slower, probably diffusion-controlled chemical reaction. According to the analysis of the

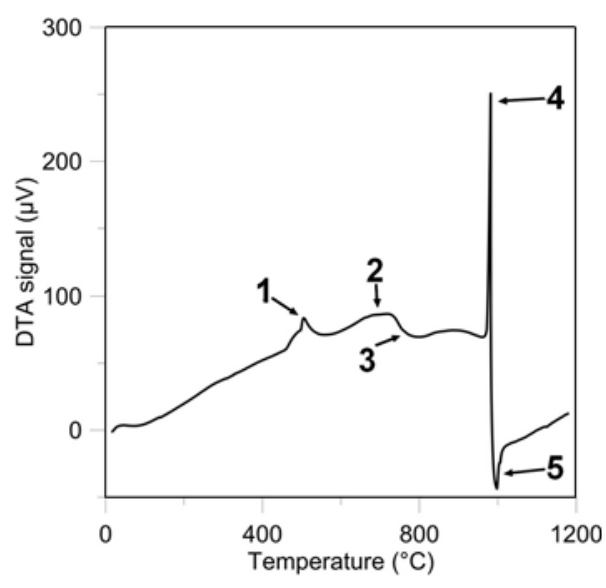

Fig. 3. DTA heating curve of the Ni-Ti-Mg5 compressed powder mixture.

\begin{tabular}{|c|c|c|}
\hline $\begin{array}{ll}1-\mathrm{Ti} & 3-\mathrm{Mg} \\
2-\mathrm{Ni} & 4-\mathrm{Ti}_{2} \mathrm{Ni}\end{array}$ & $\begin{array}{l}5-\mathrm{MgNi}_{2} \\
6-\mathrm{NiTi} \text { (austenite) }\end{array}$ & $\begin{array}{l}7-\mathrm{NiTi} \text { (martensite) } \\
8-\mathrm{Ni} 3 \mathrm{Ti}\end{array}$ \\
\hline 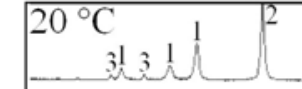 & 1 & $1 \quad 1.2$ \\
\hline $600^{\circ} \mathrm{C}$ & 1 & 1.2 \\
\hline $\left.51 \quad 15)^{3}\right)^{4}$ & 21 & 1.2 \\
\hline$\frac{800^{\circ} \mathrm{C}}{900^{\circ} \mathrm{C} \quad 5.7^{5} 7^{6}+7^{8}}$ & 46 & 1.5 \\
\hline $1000^{\circ} \mathrm{C}_{5.7} 5.7^{6}{ }^{7} 8$ & 46 & 5 \\
\hline $1100^{\circ} \mathrm{C}_{5.7} 7647$ & 4 & \\
\hline 40 & $\begin{array}{cc}50 & 60 \\
\text { Theta(degree) }\end{array}$ & 70 \\
\hline
\end{tabular}

Fig. 4. XRD patterns of NiTiMg5 (in wt.\%) alloy prepared by a reactive sintering process at $20,600,800,900,1000$, and $1100{ }^{\circ} \mathrm{C}$.

sample annealed at the temperature of this peak (at $800^{\circ} \mathrm{C}$ ), the NiTi shape memory phase forms in this temperature range (Figs. 4 and 5b). This phase had been previously detected already at $650{ }^{\circ} \mathrm{C}[21]$, but the observable amount was formed after long annealing times (three hours and longer time). In the case of $\mathrm{Ni}-\mathrm{Ti}-\mathrm{Mg}$ mixture, the reaction resulting in the formation of NiTi phase is probably supported by the partial melting due to the eutectic reaction between magnesium and $\mathrm{MgNi}_{2}$ at $506{ }^{\circ} \mathrm{C}$ [22], where the melt can act as a transport medium.

The porous structure starts to be created at the 

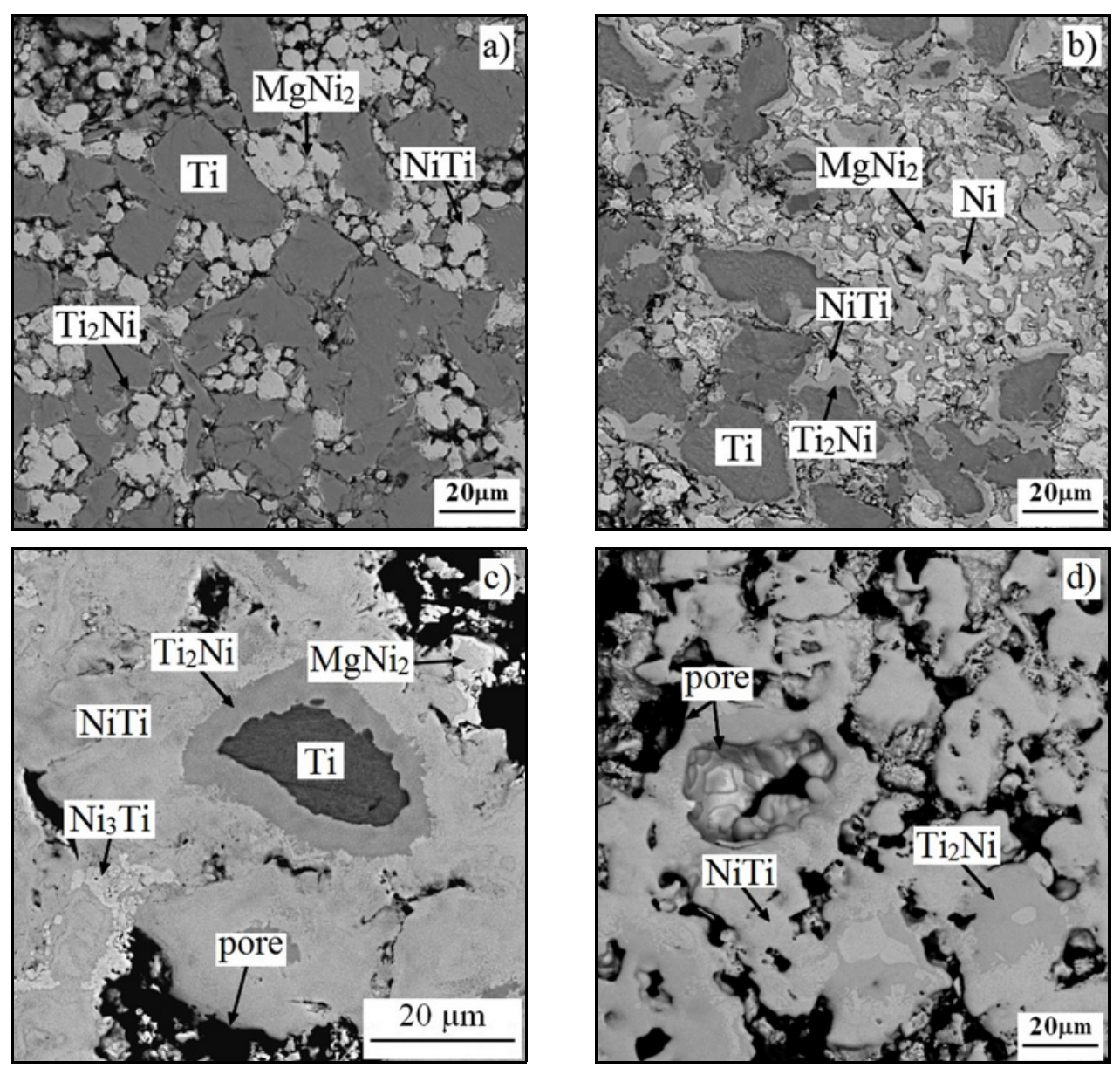

Fig. 5. The microstructure of NiTiMg5 (in wt.\%) alloy sintered at a) $600{ }^{\circ} \mathrm{C}$, b) $800^{\circ} \mathrm{C}$, c) $900^{\circ} \mathrm{C}$, and d) $1000^{\circ} \mathrm{C}$.

temperature of $900^{\circ} \mathrm{C}$ (Fig. $5 \mathrm{c}$ ), $\mathrm{Ni}_{3} \mathrm{Ti}$ phase substitutes unreacted nickel particles, and the area fraction of unreacted titanium decreases significantly, too. For the formation of porosity in SHS products there exist some possible reasons: existing pores in the compressed reactants mixture, differences in molar volume between reactants and products, unbalanced diffusion rates of nickel and titanium (Kirkendall porosity), gas evolution during reaction, and thermal migration due to the high-temperature gradient during combustion $[12,23]$. In our case, gas evolution during the exothermic SHS reaction is the most probable reason because magnesium can be evaporated at lower temperatures due to vacuum in silica ampoule. It can explain the weak endothermic effect (labelled 3) on the DTA curve between temperatures of $720-790^{\circ} \mathrm{C}$ (Fig. 3). The porosity of sample NiTiMg5 sintered at $1100^{\circ} \mathrm{C}$ was measured with result 33.9 vol.\% (porosity of $\mathrm{Ni}-\mathrm{Ti} 46=9.6$ vol. $\%$ ).

The third exothermic effect - the greatest one was observed with the maximum at $981^{\circ} \mathrm{C}$ (labelled 4 ), accompanying the SHS reaction. The porous structure was created (Fig. 5d) and four phases (NiTi, $\mathrm{Ti}_{2} \mathrm{Ni}, \mathrm{MgNi}_{2}$, and $\mathrm{Ni}_{3} \mathrm{Ti}$ ) were determined by XRD analysis (Fig. 4). The microstructure contains the small remainder of $\mathrm{MgNi}_{2}$ phase only, which undergoes the eutectic transformation $\left(1097^{\circ} \mathrm{C}\right)$ and melts (at $1147^{\circ} \mathrm{C}$ ) during very exothermic SHS reaction. Magnesium evaporates during the reaction, while the nickel from $\mathrm{MgNi}_{2}$ phase is ready for the formation of $\mathrm{Ni}_{3} \mathrm{Ti}$ phase. This last exothermic peak is followed by endothermic peak (labelled 5), which is probably caused by decomposition of residual $\mathrm{MgNi}_{2}$ phase by eutectic reaction [22] and by evaporation of magnesium in a low-pressure environment. The evaporation of magnesium was confirmed by a low content of magnesium in SHS product - Ni53.54Ti45.75Mg0.72 (in wt. $\%)$.

The high heating rate suppressed the formation of undesirable phases (there is no time for slow diffusion controlled reactions). It is the reason why the sample prepared at $1100^{\circ} \mathrm{C}$ (Fig. 2) with heating rate $300{ }^{\circ} \mathrm{C}$ min $^{-1}$ contained a lower amount of undesirable $\mathrm{Ti}_{2} \mathrm{Ni}$ and $\mathrm{MgNi}_{2}$ phases, and $\mathrm{Ni}_{3} \mathrm{Ti}$ phase was not formed. The $\mathrm{MgNi}_{2}$ phase was not observed in the microstructure in Fig. 2, it was detected only by XRD analysis. The austenite and martensite structures of NiTi phase were found in this sample. Magnesium ab- 
sorbed oxygen, and then it was evaporated at a higher temperature. Nickel (coming from $\mathrm{MgNi}_{2}$ phase) reacted with Ti-rich regions leading to form NiTi phase. Evolution of intermetallics in microstructure of Ni-Ti- Mg alloy is similar to Ni-Ti alloy, in which NiTi phase becomes major phase above the temperature of $900^{\circ} \mathrm{C}$. The addition of magnesium decreases the amount of the $\mathrm{Ti}_{2} \mathrm{Ni}$ phase in microstructure by the use of high heating rate and sintering temperature of $1100^{\circ} \mathrm{C}$.

\section{Conclusions}

In summary, the addition of 5 wt. $\%$ magnesium into Ni-Ti46 wt.\% powder mixture influences the reaction mechanism of the self-propagating high-temperature synthesis. The $\mathrm{MgNi}_{2}$ and $\mathrm{Ti}_{2} \mathrm{Ni}$ phases are formed before the NiTi phase by diffusion controlled reactions using heating rate of $20^{\circ} \mathrm{C} \mathrm{min}{ }^{-1}$. The NiTi phase together with a small amount of $\mathrm{Ti}_{2} \mathrm{Ni}$ and $\mathrm{MgNi}_{2}$ phases contain an alloy prepared by use of high heating rate $\left(300^{\circ} \mathrm{C} \mathrm{min}^{-1}\right)$, most of the magnesium addition was evaporated during the exothermic reaction at a temperature of $981^{\circ} \mathrm{C}$.

\section{Acknowledgements}

Financial support from specific university research (MSMT No 20-SVV/2016) and Czech Science Foundation, project No. 14-03044S.

\section{References}

[1] Li, X. D., Elkedim, O., Nowak, M., Jurczyk, M.: Int. J. Hydrogen Energy, 39, 2014, p. 9735. doi:10.1016/j.ijhydene.2014.04.089

[2] Lu, W.-C., Ou, S.-F., Lin, M.-H., Wong, M.-F.: J. Alloys Compd., 664, 2016, p. 193. doi:10.1016/j.jallcom.2015.12.064

[3] Mohd Jani, J., Leary, M., Subic, A., Gibson, M. A.: Mater. \& Design, 56, 2014, p. 1078. doi:10.1016/j.matdes.2013.11.084

[4] Buehler, W. J., Gilfrich, J. V., Wiley, R. C.: J. Appl. Phys., 34, 1963, p. 1475. doi:10.1063/1.1729603

[5] Frenzel, J., Zhang, Z., Neuking, K., Eggeler, G.: J. Alloys Compd., 385, 2004, p. 214. doi:10.1016/i.jallcom.2004.05.002

[6] Nayan, N., Govind, Saikrishna, C. N., Ramaiah, K. V., Bhaumik, S. K., Nair, K. S., Mittal, M. C.: Mater. Sci. Eng. A, 465, 2007, p. 44. doi:10.1016/j.msea.2007.04.039
[7] Sadrnezhad, S. K., Raz, S. B.: Metall. Mater. Trans. B, 36, 2005, p. 395. doi:10.1007/s11663-005-0068-2

[8] Elahinia, M. H., Hashemi, M., Tabesh, M., Bhaduri, S. B.: Prog. Mater. Sci., 57, 2012, p. 911. doi:10.1016/j.pmatsci.2011.11.001

[9] Novák, P., Veselý, T., Marek, I., Dvořák, P., Vojtěch, V., Salvetr, P., Karlík, M., Haušild, P., Kopeček, J.: Metall. Mater. Trans. B, 47, 2016, p. 932.

doi:10.1007/s11663-016-0589-x

[10] Novák, P., Moravec, H., Salvetr, P., Průša, F., Drahokoupil, J., Kopeček, J., Karlík, M., Kubatík, T. F.: Mater. Sci. Technol., 31, 2015, p. 1886. doi:10.1179/1743284715Y.0000000041

[11] Novák, P., Mejzlíková, L., Michalcová, A., Capek, J., Beran, P., Vojtěch, D.: Intermetallics, 42, 2013, p. 85. doi:10.1016/i.intermet.2013.05.015

[12] Whitney, M., Corbin, S. F., Gorbet, R. B.: Intermetallics, 17, 2009, p. 894. doi:10.1016/j.intermet.2009.03.018

[13] Elahinia, M., Shayesteh Moghaddam, N., Taheri Andani, M., Amerinatanzi, A., Bimber, A. B., Hamilton, F. R.: Prog. Mater. Sci., 83, 2016, p. 630. doi:10.1016/j.pmatsci.2016.08.001

[14] Jabur, A. S., Al-Haidary, J. T., Al-Hasani, E. S.: J. Alloys Compd., 578, 2013, p. 136. doi:10.1016/j.jallcom.2013.05.029

[15] Sina, H., Surreddi, K. B., Iyengar, S.: J. Alloys Compd., 661, 2016, p. 294. doi:10.1016/j.jallcom.2015.11.105

[16] Duerig, T., Pelton, A., Trepanier, C.: Nitinol - PART I. Mechanisms and Behavior. SMST e-Elastic Newsletter. Materials Park, ASM International 2011.

[17] Suresh, K. S., Kim, D. I., Bhaumik, S. K., Suwas, S.: Intermetallics, 44, 2014, p. 18. doi:10.1016/j.intermet.2013.08.005

[18] Qiu, A.-T., Liu, L.-J., Pang, W., Lu, X.-G., Li, C.-H.: Transactions of Nonferrous Metals Society of China, 21, 2011, p. 1808. doi:10.1016/S1003-6326(11)60935-7

[19] Rostoker, W.: Journal of Metals. Trans. AIME, 203, 1955, p. 113.

[20] Salvetr, P., Novák, P., Moravec, H.: Manufacturing Technology, 15, 2015, p. 689.

[21] Novák, P., Pokorný, P., Vojtěch, V., Knaislová, A., Školáková, A., Čapek, J., Karlík, M., Kopeček, J.: Mater. Chem. Phys., 155, 2015, p. 113. doi:10.1016/j.matchemphys.2015.02.007

[22] Massalski, T.: Binary Alloy Phase Diagrams. Materials Park, ASM International 1990.

[23] Li, B. Y., Rong, L. J., Li, Y. Y., Gjunter, V. E.: Acta Mater., 48, 2000, p. 3895. doi:10.1016/S1359-6454(00)00184-1 